\title{
Fire strikes Jackson Laboratory
}

A FIRE last week at the Jackson Laboratory in Bar Harbor, Maine, severely damaged the laboratory's production facility, killing some 500,000 mice and putting a halt to shipment of numerous unique strains of mice. By the week's end, officials had determined that none of the foundation stock had been lost, and Kenneth Paigen, incoming director of the laboratory, was bravely predicting that shipments would resume within 60 days. But it will be many months, if not years, before pre-fire conditions can be restored.

"This is a catastrophe", says immunologist Gerald Callahan of the University of Colorado, Colorado Springs, a common reaction to news of the fire. Although not the largest supplier of mice by volume, Jackson Laboratory is not only the sole source of certain mouse strains, but JAX mice are famous for their genetic purity and freedom from disease. The unique strains C57BL/6J-db and C57BL/KsJ-db have become extremely popular in diabetic research. Other strains in high demand are a dystrophic mutant 129/ReJ-dy and a lymphoproliferation mutant MRL/MpJlpr used for studies of immune disorders.

The laboratory distributes approximatNUCLEAR POWER

\section{Washington}

ely 2-3 million mice a year drawn from 1,700 different strains. The $\$ 10-12$ million in revenue from mouse sales is used to support research at the laboratory.

The fire started shortly after one in the afternoon. Four workmen were remodelling a room in the one-storey production facility when a volatile solvent for an adhesive they were using caught fire. Twenty-four hours later the fire was still smouldering. None of the research buildings on campus was damaged, and the production facilities for the mice used by Jackson researchers will not he affected by the fire. Foundation stocks exist either as live breeding pairs or frozen embryos.

For some at the Bar Harbor facility, last week's fire brought a chilling sense of déjà $v u$. In 1947, a fire completely razed the laboratory - as well as part of the island community where it is located - destroying all mouse stocks. The present laboratory's genetic stocks were rebuilt at that time from donations from laboratories all over the world.

Paigen, who will take over as director of the laboratory later this year, was visiting the laboratory last week, and had left for the airport to return to the University of California at Berkeley where he is on the

\section{Indian energy agency blasted}

\section{New Delh}

POOR planning and management have resulted in construction delays, lost revenue and reduced capacity for India's nuclear power industry according to two government reports released two weeks ago. The Department of Atomic Energy (DAE) was also accused of slipping up on quality control by accepting substandard pipes meant to carry toxic nuclear wastes from the Narora Atomic Power Plant commissioned last March. But DAE says that delays and cost escalations are an unavoidable result of greater self-reliance and use of indigenous nuclear technology.

The parliamentary public accounts committee, which keeps an eye on financial mismanagement in government projects, criticized DAE for its management of its heavy-water plants and the two reactors of the Madras Atomic Power Plant (MAPP). The committee claimed that DAE had not carried out an adequate site evaluation nor did the agency make a realistic assessment of the industrial infrastructure. As a result, production targets constantly slipped. MAPP-1 was eight-and-half years behind schedule and MAPP-2 took nine-and-half years longer than expected to complete. The cost of the project rose from Rs1,320 million to $\mathrm{Rs} 2,460$ million.

The accounts committee said poor planning forced one of the Madras reactors to NATURE · VOL $339 \cdot 18$ MAY 1989 pipeline had to be dug out and replaced with stainless steel pipes after the defects were revealed.
K.S. Jayaraman faculty when news of the fire brought him racing back to the laboratory.

In addition to the good news about the foundation stocks, Paigen says that at least a portion of the production facility was protected from total devastation, and may be restored. In the meantime, the laboratory plans to look for temporary quarters off campus. Other breeders, notable Harlan Sprague Dawley and Taconic, have offered to pick up some of the production capacity until Jackson Laboratory can get back on its feet. Paigen says he hopes that shipments can resume in 30-60 days, although he admits "there may only be two mice on that truck". Joseph Palca

\section{HDTV}

\section{Europeans unperturbed}

\section{Paris}

HIGH-definition television (HDTV) is a new arena for intense competition between US, Japanese and European manufacturers, but the three-way tug-of-war over norms looks set to end in a stalemate. As the Japan Broadcasting Corporation (NHK) gears up to begin broadcasting daily highdefinition pictures via its BS-2 satellite next month, US manufacturers have decided to follow the Europeans by pooling capital and seeking government aid.

On Tuesday 9 May, the American Electronics Association, a trade group of more than 3,500 companies, asked Congress for $\$ 1,350$ million in grants and loans to give the US electronics industry sufficient muscle to win a share of what seems likely to be a lucrative market, with valuable spin-off in semiconductor technology (see Nature 338, 106; 1989). Industry-wide collaborative research has long been practised in Japan and provided the model for Europe's EUREKA programme, which chose HDTV as one of its first projects in June 1986.

But the dream of a multi-million dollar world market for HDTV shows every sign of evaporating now that the United States no longer intends to adopt the Japanese $\mathrm{Hi}$ Vision norm of 1,125 lines at $60 \mathrm{~Hz}$. Both US and European designers have chosen a simple doubling of existing standards, giving 1,050 lines in the US and 1,250 lines in Europe, much to the chagrin of Japanese manufacturers who had hoped to adopt a universal norm.

Meanwhile, more than 30 European manufacturers, led by Thomson, ThornEMI, Bosch and Philips are confident that their system is the best. The $\$ 220,000$ million EUREKA project already has operational prototype HDTV receivers using the TDF-1 broadcasting satellite launched last year and manufacturers could begin production in 1990. The European Commission's JESSI programme, launched in February to develop new-generation semiconductors (see Nature 337, 682;

1989), should help. Peter Coles 